\title{
Extreme diversity and multiple SCCmec elements in coagulase-negative Staphylococcus found in the Clinic and Community in Beijing, China
}

\author{
Xiao-Ping Chen ${ }^{1 \dagger}$, Wen-Ge Li ${ }^{1 \dagger}$, Hao Zheng ${ }^{1}$, Hai-Yan Du², Li Zhang ${ }^{2}$, Lei Zhang ${ }^{2}$, Jie Che ${ }^{1}$, Yuan Wu' \\ Shu-Mei Liu ${ }^{2,3^{*}}$ and Jin-Xing Lu' ${ }^{1,4^{*}}$
}

\begin{abstract}
Background: Coagulase-negative staphylococci (CoNS) are recognized as a large reservoir of staphylococcal cassette chromosome mec (SCCmec) harboured by Staphylococcus aureus. However, data of SCCmec in CoNS are relatively absent particularly in China.

Methods: Seventy-eight CoNS clinical and 47 community isolates were collected in Beijing. PCR was performed to classify SCCmec types. Under oxacillin treatment, quantitative real-time reverse transcription PCR (qRT-PCR) was performed to compare mecA mRNA levels and mRNA half-life between isolates with single SCCmec element and those with multiple one. Their growth curves were analysed. Their bacterial cell wall integrity was also compared by performing a Gram stain. All ccr complex segments were sequenced and obtained ccr segments were analysed by phylogenetic analyses.

Results: All 78 clinical isolates had mecA segments compared with 38\% in community isolates (total 47). Only 29\% clinical isolates and 33\% community isolates (among mecA positive isolates) harboured a single previously identified SCCmec type; notably, $17 \%$ clinical isolates and 28\% community isolates had multiple SCCmec types. Further studies indicated that isolates with multiple SCCmec elements had more stable mecA mRNA expression compared with isolates with single SCCmec elements. CoNS with multiple SCCmec elements demonstrated superior cell wall integrity. Interestingly, phylogenetic analyses of obtained $70 \mathrm{ccr}$ segments indicated that horizontal gene transfer of the ccr complex might exist among various species of clinical CoNS, community CoNS and S. aureus.

Conclusions: CoNS recovered from patients carried extremely diverse but distinctive SCCmec elements compared with isolates from the community. More attention should be given to CoNS with multiple SCCmec not only because they had superior cell wall integrity, but also because CoNS and S. aureus might acquire multiple SCCmec through the ccr complex.
\end{abstract}

Keywords: Coagulase-negative staphylococci, Multiple SCCmec, Bacterial cell wall integrity

\footnotetext{
*Correspondence: Ismlucky@126.com; lujinxing6688@yahoo.com

${ }^{+}$Xiao-Ping Chen and Wen-Ge Li contributed equally to this work

${ }^{3}$ FuXingMenWai Road 20, XiCheng, Beijing 100038, China

${ }^{4}$ Changbai Road 155, ChangPing, Beijing 102206, China

Full list of author information is available at the end of the article
} provided you give appropriate credit to the original author(s) and the source, provide a link to the Creative Commons license, and indicate if changes were made. The Creative Commons Public Domain Dedication waiver (http://creativecommons.org/ publicdomain/zero/1.0/) applies to the data made available in this article, unless otherwise stated. 


\section{Background}

Coagulase-negative staphylococcus (CoNS) is a part of the commensal bacterial microflora of healthy people. However, with the development of interventional therapy and the increasing number of immunocompromised patients, these bacteria are becoming the most important causes of nosocomial infections [1,2]. CoNS bloodstream infections have been estimated in as many as 250,000 cases annually in the US. The mortality rate of these infections is $1-25 \%$, representing a great burden to the public health system [3]. The most common CoNS in nosocomial infection are Staphylococcus epidermidis, followed by Staphylococcus haemolyticus, Staphylococcus hominis and Staphylococcus capitis [4]. Another important reason for the increasing concern for CoNS is the fact that they also harbour SCCmec elements, which are found in methicillin-resistant $S$. aureus (MRSA). SCCmec elements harbour mec genes ( $m e c A / m e c C)$, providing resistance to methicillin and nearly all other beta-lactam antibiotics [5].

In general, $\mathrm{SCCmec}$ has two essential components, i.e., the mec gene complex and the cassette chromosome recombinase $(\mathrm{ccr})$ gene complex. The mec gene complex consists of $m e c A / m e c C$, regulatory genes and associated insertion sequences and has been classified into five main classes, i.e., class A, class B, class C1, class C2, class D, which has been observed only in Staphylococcus caprae, and newly found class E [6,7]. Encoding recombinases mediating integration and excision of SCCmec into and from the chromosome, $c c r$ genes $(c c r C$ or the pair of $\operatorname{cr} A$ and $\operatorname{crB}$ ) play an important role in the transfer of SCCmec elements [8]. The ccr gene(s) and surrounding genes form the $c c r$ gene complex. At present, two distinct $c c r$ gene complexes have been reported based on the composition of $c c r$ genes, one carrying two adjacent $c c r$ genes, $c c r A$ and $c c r B$, and the second carrying $c c r C$. The $c c r A$ and $c c r B$ genes identified in $S$. aureus strains are categorized into four and five allotypes respectively, resulting in six $c c r$ gene complex types, designated as type 1 (ccrA1B1), type 2 (ccrA2B2), type 3 (ccrA3B3), type 4 (ccrA4B4), type 7 (ccrA1B6) and type 8 (ccrA1B3). In contrast, all identified $c c r C$ variants to date show high nucleotide similarity and are designed to only one allotype, $c c r C 1$, constituting type 5 of $c c r$ gene complex [7, 9]. Because of the high diversity of $c c r$ gene complex and mec gene complex, an extensive genetic diversity of SCCmec elements has been revealed in $S$. aureus and a total of twelve types of SCCmec have been assigned for S. aureus based on the classes of the mec gene complex and $c c r$ gene complex [9].

Previous studies have found that specific SCCmec elements, or components, exist in particular CoNS.
For example, type IV was preferentially associated with S. epidermidis and type V was prevalently found in $S$. haemolyticus in the hospital $[10,11]$. However, in recent years, more diverse SCCmec elements including non-mecA-encoding cassettes had been revealed from CoNS, and many SCCmec elements in methicillin-resistant CoNS (MR-CoNS) could not be typed using currently available schemes applied to MRSA. Moreover mecA gene has been found more widely distributed among CoNS than among $S$. aureus indicating a potential reservoir for the transfer of SCCmec elements to $S$. aureus $[10,12,13]$. However, only a small number of SCCmec elements of CoNS have been characterized in China [14]. In addition, the precise role of SCCmec elements of CoNS in the emergence and evolution of MRSA remains obscure, which requires characterization of additional SCCmec elements. Furthermore, multiple SCCmec have been found in CoNS recovered from patients in several studies [14, 15]. To obtain information on the SCCmec of local CoNS in Beijing and to reveal the function of multiple SCCmec in CoNS, clinical and community isolates were investigated and the features (including mecA mRNA quantity, mRNA half life, growth curve, bacterial cell wall integrity) of CoNS with multiple SCCmec elements were compared with those harbouring a single SCCmec element.

\section{Methods}

\section{Sample collection and bacterial isolation}

Only one isolate from each subject was collected and further analysed in the study. The demographic, hospital, and microbiological data were anonymously collected. Clinical CoNS isolates were collected from two hospitals in Beijing from July 2013 to December 2015. These CoNS strains were isolated from the blood of inpatients. The ages ranged from 34 to 98 years (mean $\pm \mathrm{SD}$, $50 \pm 16$ ). These patients were hospitalized for more than $48 \mathrm{~h}$ and were suspected of having a blood bacterial infection. Collected blood samples were inoculated into aerobic BacT/Alert FAN blood culture bottles and incubated in the BACT/Alert machine (bioMérieux, Marcy l'Etoile, France) for up to 5 days. Positive culture samples were directly inoculated onto Mueller-Hinton Broth ( $\mathrm{MH}$ broth, Oxoid LID, Basingstoke, Hampshire, England) supplemented with $2 \% \mathrm{NaCl}$ and incubated aerobically at $37{ }^{\circ} \mathrm{C}$ for $72 \mathrm{~h}$. Species identification were determined using the Vitek II (bioMerieux, Durham, NC, USA) automated microbiology system and further confirmed by partially sequencing $16 \mathrm{~S}$ rRNA genes amplified with primers $5 \mathrm{~F}$ and $1194 \mathrm{R}$ and $r p o B$ genes with primers 2491F and 3241R [13]. 
Community CoNS isolates were collected from healthy subjects (aged from 20 to 48) in two communities in Beijing in June 2016. Three groups of subjects, including office workers, construction workers and soldiers, were recruited. Samples were collected from the forehead and elbow with cotton swabs wetted with sterilized PBS. The swabs were placed into Mueller-Hinton Broth (MH broth, Oxoid LID, England) supplemented with $2 \% \mathrm{NaCl}$ and incubated aerobically at $37{ }^{\circ} \mathrm{C}$ for $72 \mathrm{~h}$. Ten microliters of culture suspected of bacteria growth were inoculated onto Brain Heart Infusion (BHI, Oxoid LID, England) agar and suggestive colonies with white color and smooth edge were subjected to screening tests with partial sequencing of $16 \mathrm{~S}$ rRNA and $r p o B$ genes as described above.

\section{Detection of mec gene and SCCmec typing}

The existence of the $m e c A$ gene was identified using primers met $1 /$ met 2 and $m e c C$ gene with primers mecCF/ mecCR $[5,16]$. For mecA positive isolates, SCCmec typing was defined by the combination of $c c r$ type and mec class, which were obtained using PCR [6, 9]. The mec class was assigned with five primers to identify the gene lineages of mecA-mecI (class A mec with primer $\mathrm{mA} 7 / \mathrm{mI}$ ), $m e c A$-IS1272 (class B mec with primer mA7/IS7), mecAIS431 (class $C$ mec with primer mA7/IS2) and mecAIS431L (class $\mathrm{C} 1$ mec with primer $\mathrm{mA}$ /IS2L). To further discriminate class $\mathrm{C} 1$ or $\mathrm{C} 2$ mec complexes, sequences between IS431 and mecA were examined using PCR with primer (IS431-F2 or IS431-R1) located in either direction of IS431 paired with primer mecA-R2 in mecA [14]. Five $c c r$ gene complexes were identified with eight primers: four primers consisting of a common reverse primer (common to $c c r B 1-3$, i.e., primer $\mathrm{BC}$ ) and three forward primers specific for ccrA1, ccrA2, and ccrA3 to confirm $c c r 1-3$ based on differences in $c c r A$ genes; two primers to identify $c c r 4$; and two primers to identify $\operatorname{ccr} C[6,11]$.

For mecA negative isolates, $c c r$ complexes were also analysed with primers as described above. The primers and lengths of amplicons used to identify the mec gene, $m e c A$ classes and $c c r$ complexes are listed in Additional file 1: Table S1. PCR products of $c c r$ complexes from all isolates were sent to Sangon Biotechnology Company (Sangon Biotech, Shanghai, China) for sequencing. The results were blasted with sequences in GenBank, and $c c r$ genes with nucleotide identities more than $85 \%$ were designed to the same allotype [9].

Those with two mecA classes were designated CoNS with multiple SCCmec elements; those with one class of $m e c A$ complex and one $c c r$ complex detected were classified into CoNS with a single SCCmec element. All strains with multiple SCCmec elements and those with single elements were further characterized.

\section{Determination of minimal inhibitory concentrations (MIC)} to oxacillin

For MIC determination, a broth microdilution broth susceptibility assay was performed according to CLSI guidelines [17]. The oxacillin (oxacillin sodium monohydrate, Sigma-Aldrich, St. Louis, MO, USA) concentration ranged from 256 to $0.125 \mu \mathrm{g} / \mathrm{ml}$. The plates were incubated under normal atmospheric conditions for $24 \mathrm{~h}$ at $37^{\circ} \mathrm{C}$. The presence of a white pellet on the bottom of the tube indicated bacterial growth. The MIC value was identified by the lowest concentration of oxacillin at which no visible growth could be observed.

\section{Growth curves of CoNS under oxacillin treatment}

Samples of bacterial culture were prepared as follows: a single colony of the strain was cultured with $\mathrm{MH}$ broth overnight at $37{ }^{\circ} \mathrm{C}$. Bacterial suspensions were diluted with $\mathrm{MH}$ broth to $0.5 \mathrm{McF}$ arland standards and added to oxacillin (final concentration $2 \mu \mathrm{g} / \mathrm{ml}$ ) and cultured at $37^{\circ} \mathrm{C}$. Two millilitres of culture was removed at the indicated time point. The growth curves were measured by plate counts on MHI agar (Oxoid LID, Basingstoke, Hampshire, England). The experiments were repeated three times, and the results were reported as an average of the replicate samples.

\section{Quantification of mecA mRNA in CoNS under oxacillin treatment}

Samples of bacterial culture were prepared as described above. Total RNA was extracted using the OMEGA bacterial RNA kit (OMEGA Biotech, Doraville, GA, USA)

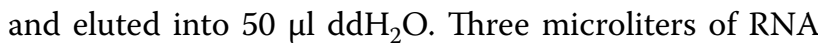
was reverse transcribed into cDNA using the TransScript TM Two-Step RT-PCR Super Mix (TransGene Biotech, Beijing, China) in a total volume of $20 \mu \mathrm{l}$. Using standard PCR and real-time PCR, $2 \mu \mathrm{l}$ of cDNA was used to evaluate and represent the quantity of total mecA mRNA in each $2 \mathrm{ml}$ sample because it held the same proportion of total RNA in each sample.

For standard PCR, $2 \mu \mathrm{l}$ of cDNA was amplified via PCR with TransScript $2 \times$ PCR Super Mix (Transgene Biotech, Beijing, China) in a total volume of $30 \mu \mathrm{l}$. The primer pairs (mecAF/mecAR) are shown in Additional file 1: Table S1 [18].

For qRT-PCR analyses, real-time PCR amplification was performed in a total volume of $25 \mu \mathrm{l}$ containing $12.5 \mu \mathrm{l}$ of $2 \times$ SYBR Fast qPCR Mix (TAKARA, Dalian, China), $1.0 \mu \mathrm{l}$ primer and $2 \mu \mathrm{l}$ template cDNA. The specific primers (mecA-1501F, mecA-1598R) used for the detection of mecA gene are listed in Additional file 1: Table S1 [19]. Data were presented as the relative copies of mecA mRNA levels compared with that of untreated CoNS with a single SCCmec element. 


\section{mecA mRNA half-life identification}

Samples of bacterial culture were prepared as described above except with oxacillin cultured at $37{ }^{\circ} \mathrm{C}$ for $3 \mathrm{~h}$. Transcriptional arrest was induced with actinomycin $\mathrm{D}$ as references except that the dosage of actinomycin D was modified to $2 \mu \mathrm{g} / \mathrm{ml}$ according to a preliminary experiment [20]. Two millilitres of culture was removed at the indicated time point. Total RNA was extracted and subjected to mecA mRNA analyses as described above.

\section{Bacterial cell wall integrity assays}

Samples of bacterial culture were prepared as described above except with $8 \mu \mathrm{g} / \mathrm{ml}$ oxacillin treatment. Samples were collected for Gram stain at 0,1 , and $3 \mathrm{~h}$ to visualize the bacterial cell wall integrity under a microscope.

\section{Phylogenetic analyses of $c \mathrm{cr}$}

The reference sequences of the ccr complex in GenBank (Additional file 1: Table S2) and those derived here (Additional file 1: Tables S3, S4) were used to construct a phylogenetic tree. Using MEGA version 5.0, neighbourjoining trees were constructed with the maximum composite likelihood model assuming rate uniformity and pattern homogeneity.

\section{Statistical analysis}

Statistical analysis and graphic presentations were performed with Microsoft Excel XP software. The results are expressed as the average of three assays. A $P$ value of 0.05 (Student's t test) was considered significant.

\section{Results}

\section{Sample collection}

In this study, a total of 78 clinical CoNS isolates and 47 community CoNS isolates were recovered and identified to species.

\section{Identification of CoNS}

CoNS obtained from the clinic were classified into 4 different Staphylococcal species. These included S. epidermidis $(\mathrm{n}=30)$, S. hominis $(\mathrm{n}=20)$, S. capitis $(\mathrm{n}=15)$ and $S$. haemolyticus $(\mathrm{n}=13)$. However, most of the CoNS recovered from community were $S$. epidermidis $(\mathrm{n}=40)$, and the other CoNS were few, including S. hominis $(\mathrm{n}=5)$ and $S$. haemolyticus $(\mathrm{n}=2)$.

\section{Extremely diverse SCCmec types and multiple SCCmec elements}

No $m e c C$ gene was detected in all these isolates. Not surprisingly, mecA was detected in $100 \%$ (78/78) clinic isolates compared to $38 \%(18 / 47)$ of the community isolates. The SCCmec typing results of these isolates are summarized in Table 1. Interestingly, only a small portion of
CoNS were assigned as harbouring a single previously identified SCCmec type in both the clinical and community strains $(23 / 78,29 \%$ and $6 / 18,33 \%$, respectively). Those identified in clinical isolates included SCCmec type III $(\mathrm{n}=7)$, type V $(\mathrm{n}=7)$, type IV $(\mathrm{n}=3)$, type VIII $(\mathrm{n}=3)$, type II $(\mathrm{n}=2)$, and type IX $(\mathrm{n}=1)$. For community strains, only six strains of $S$. epidermidis were confirmed to harbour single SCCmec type II. Moreover, 11\% (9/78) of clinical CoNS and 5\% (1/18) of community isolates recovered carried a new single SCCmec type. Strains with an previously identified single SCCmec type or new single SCCmec type were assigned as CoNS with a single SCCmec element.

Interestingly, 54\% (42/78) of clinical isolates and 39\% (7/18) of community isolates (including new single SCCmec types, new types with a single $\operatorname{mec} A$ class and multiple $c c r$ complexes) could not be classified into any SCCmec type, most of them carried more than one $c c r$ complex. Surprisingly, $17 \%$ (13/78) of the clinical isolates and $28 \%(5 / 18)$ of the community isolates had two classes of SCCmec types (assigned as CoNS with multiple SCCmec elements), particularly some clinical isolates that harboured five $c c r$ complexes (i.e., $c c r A 1 B 1$, $c c r A 2 B 2$, ccrA3B3, ccrA4B4 and $c c r C)$.

Strains (both clinical and community isolates) that did not fit into the SCCmec typing criteria, including those harbouring multiple SCCmec elements, were designated new SCCmec types (total $\mathrm{n}=67$ ), which accounted for approximately $70 \%$ of the total CoNS with mecA segments determined. It was unexpected that among the 29 community strains without a $\operatorname{mec} A$ or $\operatorname{mec} C$ segment detected, 24 (83\%) contained a ccr complex. Furthermore, multiple $c c r$ complexes were detected in 5 (21\%) strains.

\section{More stable mecA mRNA transcription in CoNS with multiple SCCmec elements compared to single elements}

As shown in Fig. 1b, total mecA mRNA in CoNS with multiple SCCmec elements exhibited constant and stable expression during the $10 \mathrm{~h}$ experiment. However, total $m e c A$ mRNA in CoNS with single SCCmec element was transcribed unsteadily during this experimental course (Fig. 1a). To further assay mecA mRNA stability, mecA mRNA half-life was analysed in randomly selected $S$. epidermidis $\mathrm{H} 67$ and H30. As demonstrated in Fig. 1c, the mecA mRNA half-life was approximately 40-50 min in S. epidermidis H30. In contrast, mecA mRNA was very unstable in $S$. epidermidis H67, in which the mecA mRNA half-time probably was no more than $10 \mathrm{~min}$.

Quantitative RT-PCR analyses of randomly selected isolates further confirmed that the total mecA mRNA in $S$. epidermidis H30 demonstrated continuously sustainable expression during the $10 \mathrm{~h}$ experiment. In contrast, 
Table 1 Detection of mecA segments and SCCmec typing results of CoNS isolates

\begin{tabular}{|c|c|c|c|c|c|c|c|c|}
\hline Character of SCCmec & Source & Species & mecA PCR & mecA class & ccr type & SCCmec type & No. of isolate & Example isolate \\
\hline \multirow{12}{*}{$\begin{array}{l}\text { Previously identified single } \\
\text { SCCmec type }\end{array}$} & \multirow[t]{10}{*}{ Clinic } & \multirow[t]{2}{*}{ S. homi } & + & A & 4 & VIII & 3 & $\mathrm{H} 80, \mathrm{H} 86$ \\
\hline & & & + & $A$ & 2 & $\|$ & 1 & H59 \\
\hline & & \multirow[t]{4}{*}{ S. epid } & + & $A$ & 3 & III & 4 & $\mathrm{H} 8$ \\
\hline & & & + & $\mathrm{B}$ & 2 & IV & 3 & $\mathrm{H} 67, \mathrm{H} 11$ \\
\hline & & & + & $\mathrm{C} 2$ & 5 & V & 2 & $\mathrm{H} 81$ \\
\hline & & & + & $A$ & 2 & $\|$ & 1 & \\
\hline & & S. haem & + & $\mathrm{C} 2$ & 1 & IX & 1 & \\
\hline & & \multirow[t]{3}{*}{ S. capi } & + & $A$ & 3 & III & 3 & $\mathrm{H} 4$ \\
\hline & & & + & $\mathrm{C} 2$ & 5 & V & 5 & $\mathrm{H} 7, \mathrm{H} 26, \mathrm{H} 54, \mathrm{H} 60, \mathrm{H} 85$ \\
\hline & & & & & & Total number & 23 & \\
\hline & \multirow[t]{2}{*}{ Community } & \multirow[t]{2}{*}{ S.epid } & \multirow[t]{2}{*}{+} & \multirow[t]{2}{*}{ A } & \multirow[t]{2}{*}{2} & $\|$ & 6 & \\
\hline & & & & & & Total number & 6 & \\
\hline \multirow{6}{*}{$\begin{array}{l}\text { New identified single SCCmec } \\
\text { type }\end{array}$} & \multirow[t]{4}{*}{ Clinic } & S. homi & + & A & 1 & New & 3 & $\mathrm{H} 29, \mathrm{H} 34$ \\
\hline & & \multirow[t]{3}{*}{ S. haem } & + & $\mathrm{C} 1$ & 4 & New & 5 & $\mathrm{H} 2$ \\
\hline & & & + & $\mathrm{C} 1$ & 2 & New & 1 & \\
\hline & & & & & & Total number & 9 & \\
\hline & \multirow[t]{2}{*}{ Community } & \multirow[t]{2}{*}{ S. haem } & \multirow[t]{2}{*}{+} & \multirow[t]{2}{*}{$\mathrm{C} 1$} & \multirow[t]{2}{*}{2} & New & 1 & CJ31-1 \\
\hline & & & & & & Total number & 1 & \\
\hline \multirow{23}{*}{$\begin{array}{l}\text { New type with a single mecA } \\
\text { class and multi ccr complexes }\end{array}$} & \multirow[t]{23}{*}{ Clinic } & \multirow[t]{6}{*}{ S. homi } & + & A & 1,4 & New & 2 & $\mathrm{H} 1$ \\
\hline & & & + & $A$ & 1,2 & New & 1 & $\mathrm{H} 73$ \\
\hline & & & + & A & 2,4 & New & 2 & \\
\hline & & & + & A & 3,4 & New & 1 & $\mathrm{HA} 1$ \\
\hline & & & + & $A$ & $1,4,5$ & New & 2 & $\mathrm{H} 6$ \\
\hline & & & + & A & $1,3,4,5$ & New & 1 & \\
\hline & & S.epid & + & A & 1,3 & New & 5 & $\mathrm{H} 22$ \\
\hline & & & + & $A$ & $1,3,4$ & New & 2 & $\mathrm{H} 21$ \\
\hline & & & + & $A$ & $3,4,5$ & New & 1 & $\mathrm{H} 92$ \\
\hline & & & + & $\mathrm{C} 2$ & 4,5 & New & 1 & $\mathrm{H} 76$ \\
\hline & & & + & $\mathrm{C} 2$ & $1,2,5$ & New & 1 & \\
\hline & & & + & B & 2,4 & New & 3 & $\mathrm{H} 24, \mathrm{H} 77$ \\
\hline & & S. haem & + & A & $1,2,4$ & New & 1 & \\
\hline & & & + & $\mathrm{C} 2$ & 2,4 & New & 1 & $\mathrm{H} 28$ \\
\hline & & & + & $\mathrm{C} 2$ & 4,5 & New & 1 & $\mathrm{H} 68$ \\
\hline & & & + & $\mathrm{C} 2$ & 1,4 & New & 2 & $\mathrm{H} 15, \mathrm{H} 36$ \\
\hline & & S. capit & + & A & 3,4 & New & 1 & $\mathrm{H} 23$ \\
\hline & & & + & A & $1,2,4,5$ & New & 1 & $\mathrm{H} 37$ \\
\hline & & & + & A & $1,2,3,5$ & New & 1 & H83 \\
\hline & & & + & A & $1,2,3,4,5$ & New & 1 & $\mathrm{H} 72$ \\
\hline & & & + & $\mathrm{C} 2$ & $2,4,5$ & New & 1 & $\mathrm{H} 78$ \\
\hline & & & + & $\mathrm{C} 2$ & $1,2,4,5$ & New & 1 & \\
\hline & & & & & & Total number & 33 & \\
\hline New type with a single mecA & Community & S. epid & + & $A$ & 2,4 & New & 1 & \\
\hline class and multi ccr complexes & & & + & A & $2,4,5$ & New & 1 & \\
\hline & & & + & B & 1,2 & New & 3 & \\
\hline & & & + & B & 2,4 & New & 1 & \\
\hline & & & & & & Total number & 6 & \\
\hline
\end{tabular}


Table 1 continued

\begin{tabular}{|c|c|c|c|c|c|c|c|c|}
\hline Character of SCCmec & Source & Species & mecA PCR & mecA class & ccr type & SCCmec type & No. of isolate & Example isolate \\
\hline \multirow[t]{19}{*}{ New type with multi SCCmec } & Clinic & S. homi & + & $A, C 2$ & $1,4,5$ & New & 1 & \\
\hline & & & + & $\mathrm{A}, \mathrm{C} 2$ & $1,2,4,5$ & New & 2 & H33-2 \\
\hline & & & + & A, C2 & $1,2,3,4,5$ & New & 1 & $\mathrm{H} 62$ \\
\hline & & S.epid & + & $A, B$ & $2,4,5$ & New & 1 & \\
\hline & & & + & $A, B$ & $2,3,5$ & New & 1 & \\
\hline & & & + & $A, B$ & $2,3,4,5$ & New & 1 & $\mathrm{H} 30$ \\
\hline & & & + & $A, B$ & $1,2,3,4,5$ & New & 1 & \\
\hline & & & + & A, C2 & 1,5 & New & 1 & \\
\hline & & & + & $A, C 2$ & $2,4,5$ & New & 1 & $\mathrm{H} 87$ \\
\hline & & & + & $A, C 2$ & $1,2,3,4,5$ & New & 1 & $\mathrm{H} 57$ \\
\hline & & S. haem & + & $A, B$ & $1,2,3,4$ & New & 1 & HA11 \\
\hline & & S.capit & + & A, C2 & $1,2,4,5$ & New & 1 & $\mathrm{H} 14$ \\
\hline & & & & & & Total number & 13 & \\
\hline & Community & S. homi & + & $A, B$ & 2 & New & 1 & \\
\hline & & & + & $A, B$ & 1 & New & 1 & CV34 \\
\hline & & & + & $A, B$ & 2,4 & New & 1 & C3-1 \\
\hline & & S. epid & + & $A, B$ & 1,2 & New & 1 & \\
\hline & & & + & $A, C 2$ & 2,5 & New & 1 & \\
\hline & & & & & & Total number & 5 & \\
\hline \multirow[t]{9}{*}{ Isolates without mecA detected } & Community & S. homi & - & - & 2 & N & 2 & C13-2 \\
\hline & & S. epid & - & - & 2 & $\mathrm{~N}$ & 15 & C5-1, CJ29 \\
\hline & & & - & - & 1,2 & $\mathrm{~N}$ & 1 & \\
\hline & & & - & - & 2,5 & $\mathrm{~N}$ & 2 & \\
\hline & & & - & - & 5 & $\mathrm{~N}$ & 2 & CJ28-3 \\
\hline & & & - & - & 2,4 & N & 1 & CV33-1 \\
\hline & & & - & - & - & $\mathrm{N}$ & 5 & \\
\hline & & S.haem & - & - & 2,4 & $\mathrm{~N}$ & 1 & \\
\hline & & & & & & Total number & 29 & \\
\hline
\end{tabular}

S. homi, S. hominis; S. epid, S. epidermidis; S. haem, S. haemolyticus; S.capit, S. capitis, -, mecA negative; N, not available

the total mecA mRNA in S. epidermidis $\mathrm{H} 8$ showed very unstable transcription during this experimental course. Furthermore, the number of $m e c A$ mRNA relative copies of S. epidermidis $\mathrm{H} 8$ at many time points was significantly less than that of $S$. epidermidis H30 (lower right panel in Fig. 2). However, no significant differences in growth curves were observed between these two isolates (upper left panel in Fig. 2). Moreover, qRT-PCR of $m e c A$ mRNA transcription and growth curve assays in other $S$. epidermidis isolates and CoNS species also demonstrated the same phenomenon (Additional file 2: Figure S1).

\section{CoNS with multiple SCCmec elements demonstrated better} bacterial cell wall integrity than those carrying a single element

Randomly selected S. epidermidis H30, H57 (with multiple SCCmec elements) and S. epidermidis H8, H67 (with single $\mathrm{SCCmec}$ ) were recruited for analyses of bacterial cell wall integrity. As shown in Fig. 3, most cells of S. epidermidis H57, H30 still demonstrated Gram-positivity after $3 \mathrm{~h}$ treatment of oxacillin $(91.6 \pm 1.3,82.6 \pm 2.8 \%$, respectively). In contrast, a smaller number of cells of $S$. epidermidis H8, H67 demonstrated Gram-positivity at $3 \mathrm{~h}$ under oxacillin treatment $(12.3 \pm 1.7,14.2 \pm 2.6 \%$, respectively). The differences between $S$. epidermidis H30, H57 and S. epidermidis H8, H67 were significant $(\mathrm{P}<0.001)$.

Phylogenetic association of ccr among CoNS and S. aureus A total of $70 \mathrm{ccr}$ complex segments were sequenced successfully in this study, including 60 clinical isolates and 10 community isolates (Additional file 1: Tables S3, S4). No new ccr allotypes or alleles were identified. The $\operatorname{cr} A B$ alleles were assigned based on a BLAST search with sequences in GenBank, resulting in 13 ccrA1B1, 13 ccrA2B2, 9 ccrA3B3, 10 ccrA4B4 and 15 ccrC from clinical CoNS and $1 \operatorname{ccr} A 1 B 1,5 \operatorname{ccr} A 2 B 2$, $3 \operatorname{cr} A 4 B 4$, and 1 ccrC from community CoNS. As shown in Fig. 4, all species of CoNS recovered from patients contained various types of $c c r$ complexes 

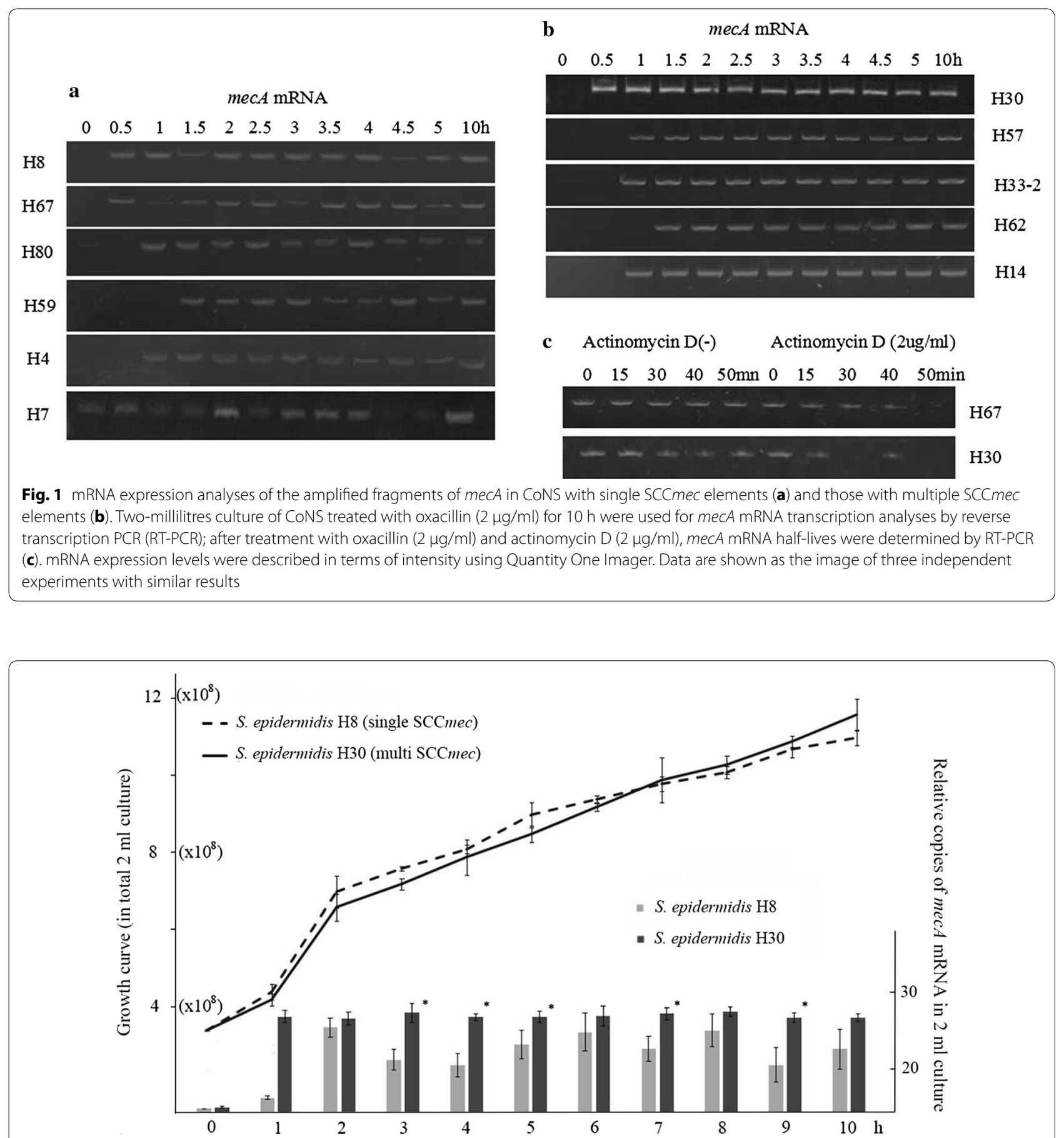

Fig. 2 Growth curve indicated total cells in a 2-ml culture of S. epidermidis H8, H30 treated with oxacillin at each time point for $10 \mathrm{~h}$ (upper left). The corresponding relative total mecA mRNA in 2-ml sample treated with oxacillin at each time point was measured by quantitative RT real-time PCR (lower right). Data were presented as the relative copies of mecA mRNA levels compared with that of S. epidermidis $\mathrm{H} 8$ ( $0 \mathrm{~h}$ ). Each bar represents the mean \pm SD of at least three independent experiments. ${ }^{*} P<0.05$ between two strains at each time point

except $c c r A 3 B 3$, which had not been discovered from S. haemolyticus in this study. For community isolates, ccrA3B3 had not been recovered in this study. In each phylogenetic tree, $c c r$ segments recovered from clinical
CoNS were grouped with those from community isolates in this study and those from around the world. No specific cluster formed for either the clinical isolates or community isolates. 


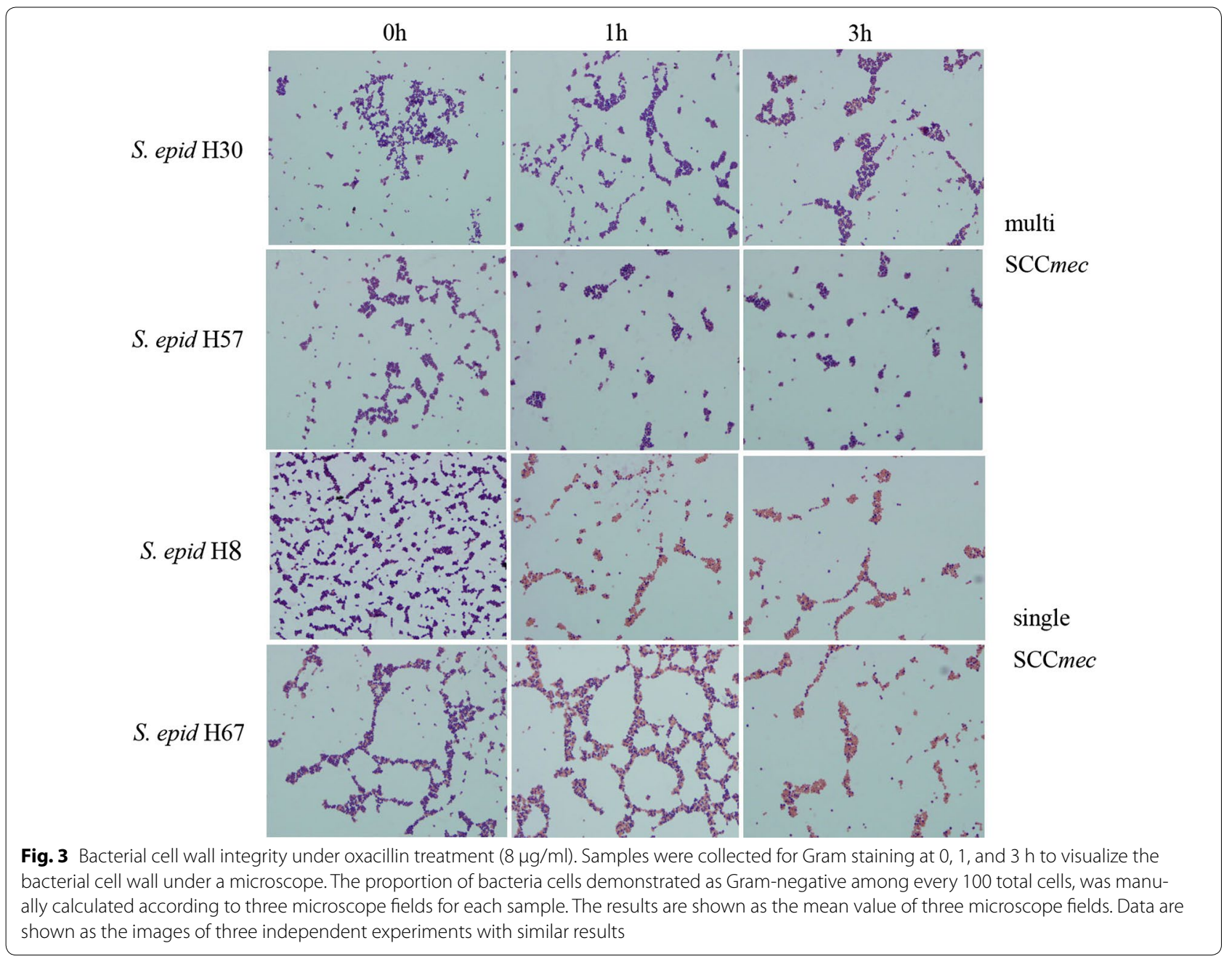

Importantly, ccrA3B3 segments in clinical CoNS demonstrated high similarity (nearly 100\%) with those in $S$. aureus worldwide. In contrast, ccrA1B1 segments from both the clinic and community were grouped together but separated from those found in $S$. aureus. Interestingly, $c c r A 2 B 2$, $c c r A 4 B 4$ and $c c r C$ showed an intermediate state, i.e., some clustered with those in $S$. aureus and others had separated from them.

\section{Discussion}

In general, the existence of different types of SCCmec in MR-CoNS is dependent on the host species and geographical locations [11]. In this study, SCCmec types, II, III, and V were prevalent in MR-CoNS in Beijing. Another study performed from southwest China demonstrated that SCCmec types III, IV and V were dominant in MR-CoNS [14]. Moreover, specific SCCmec types (in some instances, specific ccr or mec complex genes) were found particularly in specific CoNS species. Consistent with previous reports, type IV SCCmec was preferentially associated with $S$. epidermidis in our study. However, most type V SCCmec had been recovered in S. capitis in this study, unlike previous study which demonstrated type $\mathrm{V}$ dominates in S. haemolyticus [10-12]. Although in this study class $C$ mec was dominantly associated with $S$. haemolyticus as previous reports [21, 22], most S. haemolyticus isolates (clinic or community) carried new SCCmec type. We also did not find type VII SCCmec in CoNS in this study as other researchers; however, one isolate of type IX was disclosed in S. haemolyticus in clinic, which had not been previously confirmed in CoNS [12, 23]. A recent study also reported SCCmec type IX in CoNS in the community [24]. Significantly, most CoNS strains recovered in this study (clinic and community) consisted of untypable SCCmec elements as many other reports [14-16, 23, 25]. Importantly, the differences between clinical CoNS and community isolates might result from sampling bias as most CoNS recovered from the community were $S$. epidermidis. 


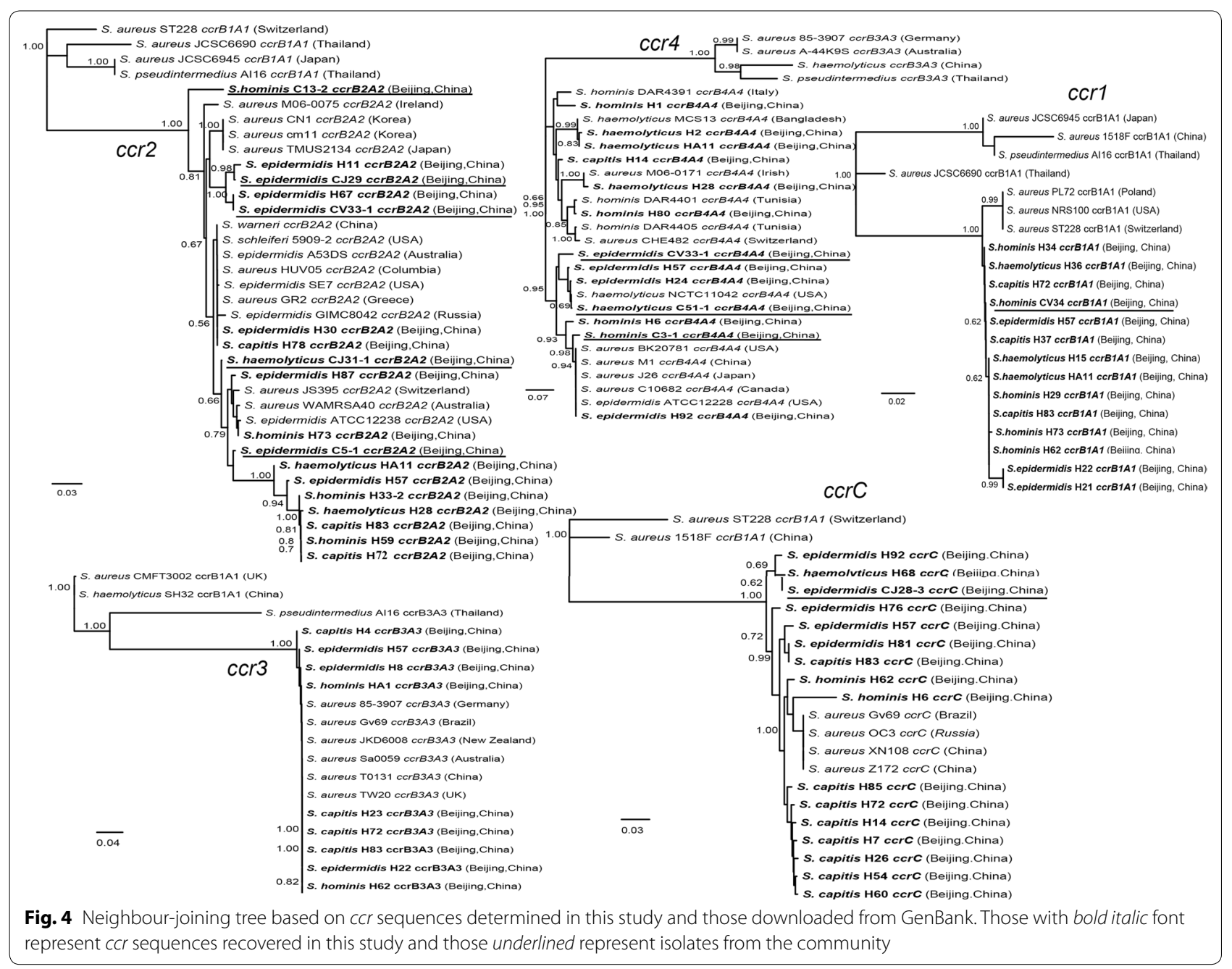

Intriguingly, various combinations of $c c r$ types were revealed in a single CoNS strain, including clinical and community isolates in this study. Multiple copies of $c c r$ complex have been reported in S. aureus, S. epidermidis and other CoNS. However, most are combinations of $\operatorname{cr} A B$ and $\operatorname{ccr} C[6,25]$. To the best of our knowledge, this is the first report of a heterogeneous combination of $c c r$ complex in a single CoNS strain, particularly all five types of $c c r$ complexes existing in a single clinical isolate. Thus, it was not surprising that these CoNS strains contained multiple SCCmec elements. Multiple SCCmec elements have been reported in clinical MR-CoNS and the incidences were as high as that observed in our finding $[6,14]$. Although it was likely that the two SCCmec elements actually constituted a composite rather than two independent units, multiple copies of mecA existed in one single CoNS strain both in the clinic and community as revealed in our study. Intriguingly, whether the existence of multiple SCCmec in community isolates was attributed to spill over from the hospital or to antibiotic abuse in the community requires further investigation.

It is well-known that acquisition of antibiotic resistance in bacterial cells is often accompanied by fitness cost in the absence of antibiotics, most of which demonstrated slower growth rates and finally resulted in the dilution of antibiotic resistant genes [26]. However, we did not identify any significant differences in the growth rates between CoNS strains with multiple SCCmec and those with a single isolate with or without oxacillin, and no correlation of multiple $\mathrm{SCCmec}$ with $\mathrm{MIC}$ in response to oxacillin was disclosed (data not shown). We speculated that MIC in response to oxacillin might also be correlated with other antibiotic genes [27]. Interestingly, we demonstrated that multiple SCCmec elements in CoNS strains ensure stable and continuous transcription of antibioticresistant genes, i.e., $m e c A$ gene, whose transcript, $\mathrm{PBP} 2 \mathrm{a}$, was capable of maintaining cell wall integrity [28]. Further analyses by Gram staining demonstrated that the cell wall in CoNS with multiple SCCmec demonstrated much 
stronger resistance and better integrity under oxacillin treatment than those CoNS with single SCCmec element. Interestingly, although the bacteria cell number dramatically increased, total mecA mRNA levels sustained constantly from $1 \mathrm{~h}$ to $10 \mathrm{~h}$ incubation with oxacillin. We suspected that the amount of mecA mRNA at the $1 \mathrm{~h}$ time point was sufficient to resist the antibiotics added into the culture.

Finally, phylogenetic analyses of $c c r$ indicated potential horizontal gene transfer among different CoNS species of clinic and community isolates, even among CoNS and S. aureus. In particular, nearly $100 \%$ similarity of all ccr $A 3 B 3$ might result from a recent gene transfer among different CoNS species and S. aureus. As observed in previous studies [16], we also detected the $c c r$ complex in mec negative strains. Specifically, some community CoNS strains had multiple $c c r$ but lacked the mec gene. Their potential to acquire mec genes with these $c c r$ complexes requires further attention. However, the limitation of our work is that we could not determine which $c c r$ complex was linked to the specific SCCmec, particularly for those that had two types of mecA classes (multiple SCCmec). The presence of untypable and multiple SCCmec elements represent great challenges for SCCmec typing in MR-CoNS [11, 14, 15, 23]. Whole genome sequencing of more MR-CoNS would be helpful to construct a new typing method through understanding the relative position and precise composition of multiple SCCmec and to further elucidate the role of $c c r$ complexes in spreading SCCmec elements among CoNS and S. aureus.

\section{Conclusions}

Overall, CoNS recovered in Beijing carried extremely diverse SCCmec elements including multiple SCCmec elements, which demonstrated superior cell wall integrity. Our data revealed potential horizontal gene transfer among different CoNS species of clinic and community isolates, even among CoNS and S. aureus.

\section{Additional files}

Additional file 1: Table S1. Primers used for mec gene detection and SCCmec Typing. Table S2. The ccr gene sequences obtained from GenBank for phylogenetic analyses. Table S3. The ccr gene sequences obtained in this study for phylogenetic analyses. Table S4. Origins of the CoNS strains whose ccr segments were applied to phylogenetic analyses.

Additional file 2: Figure S1. Growth curve indicating the total cells in a 2-ml culture of CoNS treated with oxacillin at each time point for $10 \mathrm{~h}$ (upper left in panel A, B, and C). The corresponding relative total mecA mRNA in the 2-ml sample treated with oxacillin at each time point was measured by quantitative RT real-time PCR (lower right in each panel). Data are presented as the relative copies of mecA mRNA levels compared with that of S. epidermidis $\mathrm{H} 8(0 \mathrm{~h})$. Each bar represents the mean $\pm \mathrm{SD}$ of at least three independent experiments. ${ }^{*} P<0.05$ between two strains at each time point.

\section{Abbreviations}

CoNS: coagulase-negative staphylococci; SCCmec: staphylococcal cassette chromosome mec; ccr: cassette chromosome recombinase; MIC: minimal inhibitory concentrations.

\section{Authors' contributions}

XPC, SML and JXL wrote the manuscript. XPC, WGL and HZ implemented PCR and sequence analyses; HYD, LZ, and LZ performed bacterial culture experiments; JC and YW did raw data analyses. All authors read and approved the final manuscript.

\section{Author details \\ ${ }^{1}$ State Key Laboratory for Infectious Disease Prevention and Control, Collabo- rative Innovation Center for Diagnosis and Treatment of Infectious Diseases, National Institute for Communicable Disease Control and Prevention, Chinese Center for Disease Control and Prevention, Beijing 102206, China. ${ }^{2}$ Microbiol- ogy Laboratory, Fu Xing Hospital, Capital Medical University, Beijing 100038, China. ${ }^{3}$ FuXingMenWai Road 20, XiCheng, Beijing 100038, China. ${ }^{4}$ Changbai Road 155, ChangPing, Beijing 102206, China.}

\section{Acknowledgements}

Not applicable.

\section{Competing interests}

The authors declare that they have no competing interests.

\section{Consent for publication}

Not applicable.

\section{Availability of data and materials}

All data generated or analysed during this study are included in this published article and its Additional files 1 and 2 .

\section{Ethics approval and consent to participate}

The ethics committee of National Institute of Communicable Disease Control and Prevention approved the protocol before the beginning of this research.

\section{Funding}

This work was supported by the National Key Technology Support Program (2012BAl11B05) and National Natural Science Foundation of China (Grants 81201250).

\section{Publisher's Note}

Springer Nature remains neutral with regard to jurisdictional claims in published maps and institutional affiliations.

Received: 6 February 2017 Accepted: 5 August 2017

Published online: 22 August 2017

References

1. Ghazal SS, Stevens MP, Bearman GM, Edmond MB. Utility of surveillance blood cultures in patients undergoing hematopoietic stem cell transplantation. Antimicrob Resist Infect Control. 2014;3:20.

2. Widerström M. Significance of Staphylococcus epidermidis in health careassociated infections, from contaminant to hospital relevant pathogen: this is a wake-up call! J Clin Microbiol. 2016;54:1679-81.

3. Raad I, Hanna H, Maki D. Intravascular catheter-related infections: advances in diagnosis, prevention, and management. Lancet Infect Dis. 2007;7:645-57.

4. Dong Y, Speer CP. The role of Staphylococcus epidermidis in neonatal sepsis: guarding angel or pathogenic devil? Int J Med Microbiol. 2014;304:513-20.

5. García-Álvarez L, Holden MT, Lindsay H, Webb CR, Brown DF, Curran $M D$, et al. Meticillin-resistant Staphylococcus aureus with a novel mecA homologue in human and bovine populations in the UK and Denmark: a descriptive study. Lancet Infect Dis. 2011;8:595-603. 
6. Kondo Y, Ito T, Ma XX, Watanabe S, Kreiswirth BN, Etienne J, et al. Combination of multiplex PCRs for staphylococcal cassette chromosome mec type assignment: rapid identification system for mec, ccr, and major differences in junkyard regions. Antimicrob Agents Chemother. 2007;51:264-74

7. Turlej A, Hryniewicz W, Empel J. Staphylococcal cassette chromosome mec (SCCmec) classification and typing methods: an overview. Pol J Microbiol. 2011;60:95-103.

8. Misiura A, Pigli YZ, Boyle-Vavra S, Daum RS, Boocock MR, Rice PA. Roles of two large serine recombinases in mobilizing the methicillin-resistance cassette SCCmec. Mol Microbiol. 2013;88:1218-29.

9. International Working Group on the Classification of Staphylococcal. Cassette chromosome elements (IWG-SCC). Classification of staphylococcal cassette chromosome mec (SCCmec): guidelines for reporting novel SCCmec elements. Antimicrob Agents Chemother. 2009:53:4961-7.

10. Fessler AT, Billerbeck C, Kadlec K, Schwarz S. Identification and characterization of methicillin-resistant coagulase-negative staphylococci from bovine mastitis. J Antimicrob Chemother. 2010;65:1576-82.

11. Ruppé E, Barbier F, Mesli Y, Maiga A, Cojocaru R, Benkhalfat M, et al. Diversity of staphylococcal cassette chromosome mec structures in methicillin-resistant Staphylococcus epidermidis and Staphylococcus haemolyticus strains among outpatients from four countries. Antimicrob Agents Chemother. 2009;53:442-9.

12. Ibrahem S, Salmenlinna S, Virolainen A, Kerttula AM, Lyytikäinen O, Jägerroos H, et al. Carriage of methicillin-resistant Staphylococci and their SCCmec types in a long-term-care facility. J Clin Microbiol. 2009;47:32-7.

13. Petti CA, Simmon KE, Miro JM, Hoen B, Marco F, Chu VH, International Collaboration on Endocarditis-Microbiology Investigators, et al. Genotypic diversity of coagulase-negative staphylococci causing endocarditis: a global perspective. J Clin Microbiol. 2008;46:1780-4.

14. Zong Z, Peng C, LüX. Diversity of SCCmec elements in methicillinresistant coagulase-negative staphylococci hospital isolates. PLoS ONE. 2011;6:e20191.

15. Tulinski P, Fluit AC, Wagenaar JA, Mevius D, van de Vijver L, Duim B. Methicillin-resistant coagulase-negative staphylococci on pig farms as a reservoir of heterogeneous staphylococcal cassette chromosome mec elements. Appl Environ Microbiol. 2012;78:299-304.

16. Hanssen AM, Kjeldsen G, Sollid JU. Local variants of staphylococcal cassette chromosome mec in sporadic methicillin-resistant Staphylococcus aureus and methicillin-resistant coagulase-negative staphylococci: evidence of horizontal gene transfer? Antimicrob Agents Chemother. 2004:48:285-96.

17. Clinical and Laboratory Standards Institute (CLSI). Methods for dilution antimicrobial susceptibility tests for bacteria that grow aerobically. Approved Standard M07-A8. 8th ed. CLSI: Wayne; 2009.
18. Lee JW, Ji YJ, Lee SO, Lee IS. Effect of Saliva miltiorrhiza bunge on antimicrobial activity and resistant gene regulation against methicillin-resistant Staphylococcus aureus (MRSA). J Microbiol. 2007;45:350-7.

19. Wang HY, Kim S, Kim J, Park SD, Uh Y, Lee H. Multiplex real-time PCR assay for rapid detection of methicillin-resistant staphylococci directly from positive blood cultures. J Clin Microbiol. 2014;52:1911-20.

20. Chen X, Yoza BK, El Gazzar M, Hu JY, Cousart SL, McCall CE. RelB sustains IkappaBalpha expression during endotoxin tolerance. Clin Vaccine Immunol. 2009;16:104-10.

21. Berglund C, Söderquist B. The origin of a methicillin-resistant Staphylococcus aureus isolate at a neonatal ward in Sweden-possible horizontal transfer of a staphylococcal cassette chromosome mec between methicillin-resistant Staphylococcus haemolyticus and Staphylococcus aureus. Clin Microbiol Infect. 2008;14:1048-56.

22. Bouchami $O$, Ben Hassen A, de Lencastre $H$, Miragaia M. High prevalence of mec complex $\mathrm{C}$ and $\mathrm{ccrC}$ is independent of SCCmec type V in Staphylococcus haemolyticus. Eur J Clin Microbiol Infect Dis. 2012:31:605-14.

23. Li M, Wang X, Gao Q, Lu Y. Molecular characterization of Staphylococcus epidermidis strains isolated from a teaching hospital in Shanghai, China. J Med Microbiol. 2009;58:456-61.

24. Sinlapasorn S, Lulitanond A, Angkititrakul S, Chanawong A, Wilailuckana C, Tavichakorntrakool R, et al. SCCmec IX in meticillin-resistant Staphylococcus aureus and meticillin-resistant coagulase-negative staphylococci from pigs and workers at pig farms in Khon Kaen, Thailand. J Med Microbiol. 2015;64:1087-93.

25. Hanssen AM, Sollid JU. Multiple staphylococcal cassette chromosomes and allelic variants of cassette chromosome recombinases in Staphylococcus aureus and coagulase-negative staphylococci from Norway. Antimicrob Agents Chemother. 2007;51:1671-7.

26. Suzuki S, Horinouchi T, Furusawa C. Phenotypic changes associated with the fitness cost in antibiotic resistant Escherichia coli strains. Mol BioSyst. 2016;12:414-20.

27. Wassenaar TM, Ussery D, Nielsen LN, Ingmer H. Review and phylogenetic analysis of qac genes that reduce susceptibility to quaternary ammonium compounds in Staphylococcus species. Eur J Microbiol Immunol (Bp). 2015;5:44-61.

28. Niemeyer DM, Pucci MJ, Thanassi JA, Sharma VK, Archer GL. Role of mecA transcriptional regulation in the phenotypic expression of methicillin resistance in Staphylococcus aureus. J Bacteriol. 1996;178:5464-71.

\section{Submit your next manuscript to BioMed Central and we will help you at every step:}

- We accept pre-submission inquiries

- Our selector tool helps you to find the most relevant journal

- We provide round the clock customer support

- Convenient online submission

- Thorough peer review

- Inclusion in PubMed and all major indexing services

- Maximum visibility for your research

Submit your manuscript at www.biomedcentral.com/submit
() BioMed Central 